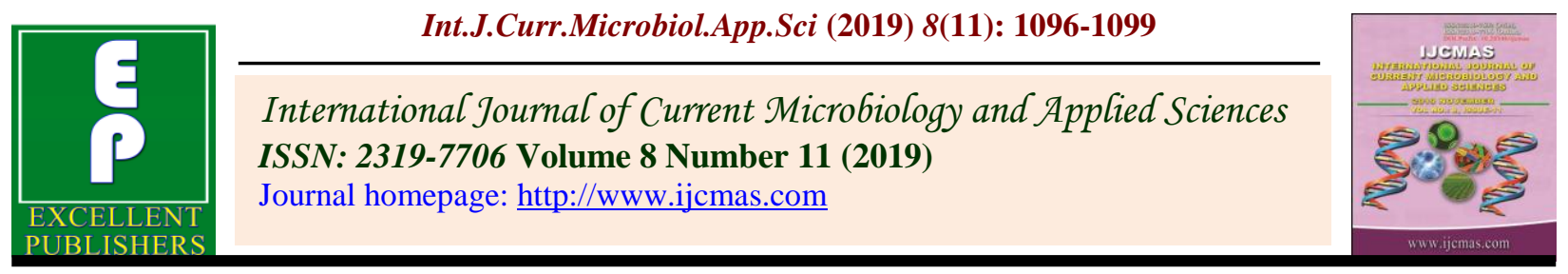

Original Research Article

https://doi.org/10.20546/ijcmas.2019.811.129

\title{
Genetic Diversity Analysis in Unique Rice (Oryza sativa L.) of Chhattisgarh, India
}

\author{
Maumita Burman*, S.K. Nair and A.K. Sarawgi \\ Department of Genetics and Plant Breeding, Indira Gandhi Krishi Vishwavidyalaya (IGKV) \\ Raipur-492012, Chhattisgarh, India \\ *Corresponding author
}

\section{A B S T R A C T}

\section{Keywords}

Unique rice, Cluster analysis, Genetic divergence, Rice germplasm

\section{Article Info}

Accepted:

10 October 2019

Available Online:

10 November 2019
Chhattisgarh is blessed with a wide variability in rice. Indira Gandhi Krishi Vishwavidyalaya, Raipur, Chhattisgarh is proudly maintaining more than 23,000 rice germplasm accessions which is presently the largest active germplasm collection of rice in India and second largest in world. The present study was carried out by using 110 unique rice genotypes including one check. Morphological and grain yield related traits were studied to assess the existence of genetic divergence by using Non-hierarchical Euclidean cluster analysis. The 110 diverse genotypes were grouped into six distinct non overlapping clusters. Among the six clusters, cluster III is the largest cluster with a maximum of 33 genotypes followed by clusters I ( 20 genotypes) and cluster V \& VI (18 genotypes each). Highest intra-cluster distance was observed in cluster IV, followed by cluster II and cluster V. It shows high variability among the genotypes of cluster IV. Highest inter-cluster distance was observed between cluster III \& IV indicating that genotypes of these groups deserves consideration for their direct use as parents in hybridization programmes to develop high yielding rice varieties. It is followed by cluster I \& IV. Cluster IV is characterized by genotypes with highest number of filled grains per panicle and total number of grains per panicle. Cluster III is having genotype with tallest plant height. Cluster II is having genotypes with high tillering capacity and yield which can be further utilized for trait specific studies.

\section{Introduction}

Rice germplasm of Chhattisgarh plays an important role in preserving and maintaining the biodiversity of rice. Rice germplasm is a very important asset that must be preserved. There is a strong need not only to conserve landrace genotypes but also broaden the genepool of rice for the future utilization in breeding of high yielding, superior quality and better adapted varieties in the country. In crop improvement programme, to increase the productivity breeder needs to maintain a pool of diverse desirable donor parents (Joshi et al., 2013). Genetic diversity plays a key role in selecting the suitable parents for hybridization programme resulting in superior hybrids and desirable transgressive segregants (Rathi et 
al., 2011). Genetic diversity in crop plants is essential to sustain level of high productivity (Tripathi et al., 2013). It is the most important tool in the hands of the plant breeder in choosing the right type of parents for hybridization programme. To make India self sufficient in rice, it is needed to improve the productivity to a greater extent (Hossain, 1996; Mishra, 2002). Keeping in view the above facts the present investigation has been undertaken to estimate genetic divergence of indigenous unique genotypes of rice and selecting divergent parents for future use in improvement.

\section{Material and Methods}

The present research work was conducted at Research Farm, Department of Genetics and Plant Breeding, Indira Gandhi Agricultural University, Raipur (Chhattisgarh) during kharif 2014. The experimental material consists of 110 unique rice genotypes collected from different districts of Chhattisgarh including one check variety of rice. Each genotype was grown in single row. Normal agronomic practices were followed throughout the crop period. Five plants from each row were randomly selected and were tagged for recording characters viz., Effective tillers per plant, Plant height $(\mathrm{cm})$, Panicle Length (cm), Filled Grains per panicle, Chaffy Grains per panicle, Total Number of Grain per panicle, Grain yield per plant and 1000 grain weight. Panicle and grain characters were recorded on five panicles of selected plants. Cluster analyses for the above characters were done by following Non Hierarchical Euclidean cluster analysis in order to classify the genotypes into different groups based on their similar and dissimilar performance for the traits. Genetic divergence among genotypes was studied through Non Hierarchical Euclidean cluster analysis. (Beale, 1969 and Spark, 1973) and genotypes were grouped into different clusters by Tocher's method (Rao,
1952). Intra and inter cluster distances and mean performance of the clusters for the characters were also computed.

\section{Results and Discussion}

Analysis by non-hierarchical Euclidean cluster method grouped 110 rice genotypes into six distinct non overlapping clusters (Table 1). It revealed the presence of substantial genetic diversity among the genotypes screened. This indicated that material under study may serve as good source for selecting the diverse parents for hybridization programme for isolating transgressive segregants for grain yield and its attributes. The existence of high degree of genetic divergence in rice has also been reported by Suman et al., 2005, Chandra et al., 2007, and Pratap et al., 2011. Sarawgi and Rostogi examined the genetic diversity in 132 genotypes of rice and placed cluster analysis in 10 different categories. Among the six clusters formed, Cluster III is the largest cluster with a maximum of 33 genotypes followed by clusters I (20 genotypes) and cluster V \& VI (18 genotypes each). Average intra and inter cluster distance in rice genotypes are presented in Table 2. Highest intra-cluster distance was observed in cluster IV, followed by cluster II and cluster V. It shows high variability among the genotypes of cluster IV. Highest inter-cluster distance was observed between cluster III \& IV suggesting wide diversity between these clusters. Therefore, genotypes of these groups deserve consideration for their direct use as parents in hybridization programmes to develop high yielding rice varieties. It is followed by cluster I \& IV. Cluster IV is characterized by genotypes with highest number of filled grains per panicle and total number of grains per panicle. Cluster III is having genotype with tallest plant height. Cluster II is having genotypes with high tillering capacity and yield which can be further utilized for trait specific studies (Table 3 ). 
Table.1 Distribution pattern of 110 rice genotypes into 6 clusters based on Non -hierarchical Euclidean Cluster Analysis

\begin{tabular}{|c|c|c|}
\hline Cluster & $\begin{array}{l}\text { Number of } \\
\text { Genotypes }\end{array}$ & Name of Genotypes \\
\hline I & 20 & $\begin{array}{l}\text { KOUDI DHULL, NAYKAIN JHABA CHINNOR, ELAYCHI, } \\
\text { ANTERVED, KUBRI MOHAR, CHEPTI GURMATIA, SUL DHAN, } \\
\text { GATHUWAN, MAHARAJI, DANWAR, BAISUR, RESARI, } \\
\text { TILKASTURI, MOKDO, PALTU, PANDUL, DUBRAJ, JALKESHAR, } \\
\text { RANI KAJAR }\end{array}$ \\
\hline II & 9 & $\begin{array}{l}\text { KADAM PHOOL, NARIYAL PHOOL, KHAJUR JHOPA, JAU PHOOL, } \\
\text { LAHSUN BHOG, CHILKAL, BHEJARI, LAYACHA, DUDH MALAI }\end{array}$ \\
\hline III & 33 & $\begin{array}{l}\text { AMA RUTHI, DO DANA, PANKHI, SUA PANKHI, MAINA GALI, } \\
\text { PAREWA, RAMALI CHONCH, PAKSHI RAJ, KARI GILAS, } \\
\text { PARMAL, ROTI, KHATIA PATI,LAYACHA, BAJARANG BALI, } \\
\text { KAPOOR SAR, BANS PATRI, CHINI KAPOOR, CHHATRI, PAPITA, } \\
\text { FARSA PHOOL, HANUMAN LANGUR, KUMHDEN, BEDA KABRO, } \\
\text { BHAINSA PUNCHHI, KATKI, KATANGI, KOYLARI, JATA } \\
\text { SHANKAR, BHAMA SUR, LANJI, AGINDHAJ, RAJA BANGLA, } \\
\text { KARMA MAHSURI }\end{array}$ \\
\hline IV & 12 & $\begin{array}{l}\text { AMA JHOPA, TULSI MANJARI, BADSHAH BHOG, BAG MUCHH, } \\
\text { KERA GHUL, MALA GOURI, SAMUDRA FAN, FUNDRI, JHILLI, } \\
\text { SHRI KAMAL, KORMA, BHAINSA MUNDARIYA }\end{array}$ \\
\hline $\mathbf{V}$ & 18 & $\begin{array}{l}\text { CHHIND GUCHCHHI, RAM LAXMAN, DOKRA DOKRI, DOKRA } \\
\text { MECHHA, CHIKO, HARDI GANTHI, BAILA AANKHI, BOKRA } \\
\text { MUNDI, JALPAN, PARWAT KALA, JAL PONGA, HANTHI } \\
\text { PANJARA, SARAI PHOOL, KURSO BHOG, BARMA TRIPAL, } \\
\text { KALIMAI, SHONTH, NARIYAL CHUDI }\end{array}$ \\
\hline VI & 18 & $\begin{array}{l}\text { KALI KAMOD, ATMA SHITAL, SHAM JIRA, JIRA DHAN, } \\
\text { DHAWARA SAWA, SUKALA PHOOL, GANGA BARU, JAI GUNDI, } \\
\text { SHYAM JIRA, TULSI PRASAD, JAL SINGA, NAWAB BHOG, SON } \\
\text { BANKO, ICHCHWATI, BHANTA PHOOL, SHITAL BHOG, SAMUND } \\
\text { CHINI, VISHNU BHOG }\end{array}$ \\
\hline
\end{tabular}

Table.2 Average intra and inter cluster distance value among 6 clusters for 110 genotypes

\begin{tabular}{|c|c|c|c|c|c|c|}
\hline Cluster & I & II & III & IV & V & VI \\
\hline I & $\mathbf{1 . 8 5 9}$ & & & & & \\
\hline II & 3.092 & $\mathbf{2 . 4 0 1}$ & & & & \\
\hline III & 2.277 & 3.903 & $\mathbf{1 . 8 0 1}$ & & & \\
\hline IV & 4.221 & 3.666 & 4.386 & $\mathbf{2 . 4 9 6}$ & & \\
\hline V & 2.948 & 3.400 & 2.497 & 3.666 & $\mathbf{2 . 4 0 0}$ & \\
\hline VI & 2.474 & 2.714 & 2.672 & 2.878 & 2.869 & $\mathbf{1 . 5 0 8}$ \\
\hline * Diagnol values in bold are intracluster & & & & \\
\hline
\end{tabular}


Table.3 Mean value of 6 clusters and contribution of different characters towards genetic divergence in 110 genotypes

\begin{tabular}{|c|c|c|c|c|c|c|c|c|}
\hline Cluster & $\begin{array}{c}\text { Effective } \\
\text { Tillers per } \\
\text { plant }\end{array}$ & $\begin{array}{c}\text { Plant } \\
\text { height } \\
\text { (cm) }\end{array}$ & $\begin{array}{c}\text { Panicle } \\
\text { Length } \\
\text { (cm) }\end{array}$ & $\begin{array}{c}\text { Filled } \\
\text { Grains Per } \\
\text { panicle }\end{array}$ & $\begin{array}{c}\text { Chaffy } \\
\text { Grains } \\
\text { Per } \\
\text { panicle }\end{array}$ & $\begin{array}{c}\text { Total } \\
\text { Number of } \\
\text { Grain Per } \\
\text { panicle }\end{array}$ & $\begin{array}{c}\text { Grain } \\
\text { Yield } \\
\text { /Plant } \\
\text { (gms) }\end{array}$ & $\begin{array}{c}\text { 1000 } \\
\text { Grain } \\
\text { Weight } \\
\text { (gms) }\end{array}$ \\
\hline I & 6.50 & 136.43 & 23.71 & 138.76 & 14.81 & 153.58 & 16.86 & 2.33 \\
\hline II & 11.00 & 137.44 & 25.74 & 173.48 & 23.18 & 196.66 & 24.09 & 1.72 \\
\hline III & 5.93 & 161.41 & 27.28 & 132.91 & 10.88 & 143.78 & 18.14 & 3.01 \\
\hline IV & 6.69 & 160.66 & 25.86 & 250.91 & 22.59 & 275.18 & 19.22 & 1.53 \\
\hline V & 5.59 & 152.18 & 27.20 & 160.33 & 32.37 & 192.15 & 23.93 & 3.24 \\
\hline VI & 7.27 & 150.11 & 28.09 & 169.79 & 22.35 & 192.14 & 15.65 & 1.41 \\
\hline
\end{tabular}

\section{References}

Beale, E. M. L. (1969). Euclidean cluster analysis. A paper contributed to 37 th session of the International statistical Institute.

Chandra, B. S., Reddy, T. D. and Ansari, N. A. (2007). Genetic divergence in rice (Oryza sativa L.). Research on Crops, 8 (3): 600-603.

Hossain M. (1996). Economic prosperity in Asia: Implications for Rice Research. In: Khush, G.S. (ed) Rice Genetics III. IRRI, Manila, Philippines. pp. 3-16.

Joshi, M., Verma, S. K., Singh, J. P. and Barh, A. (2013). Genetic diversity assessment in lentil (lens culinaris Medikus) genotypes through ISSR marker. The Bioscan. 8(4): 1529-15

Mishra M. (2002). Rice in India. Agrolook, 3:10-15.

Pratap, N., Singh P. K., Verma, Yadavendra, G. P. and Tripathi, S. (2011). Genetic divergence for yield and its component traits in aromatic and non-aromatic rice (Oryza sativa L.) germplasm. Plant Archives, 11 (2): 801-804.
Rao, C.R. (1952). Advance Statistical Methods in Biometrics Research, Hofaer Publication.

Rathi, S., Kumar, R., Munshi, A. D. and Verma, M. (2011). Breeding potential of brinjal genotypes using D2 analysis. Indian J. Hort. 68(3):328-331.

Spark, D.N. (1973). Euclidean cluster analysis. Algorithm A.58. Applied Statistics, 22: 126- 130.

Suman, A., Shankar, V. G., Rao, L. V. S. and Sreedhar, N. (2005). Analysis of genetic divergence in rice (Oryza sativa L.) germplasm. Research on Crops, 6(3): 487-491.

Sarawgi, A. K. and Rostogi, N.K..(1998). Genetic diversity for grain quality parameters in traditional rice(Oryza sativa L.). Accessions from Madhya Pradash India. Tropical Agricultural Research and Extension. 1: 2, 103-106.

Tripathi, A., Bisen, R., Ahirwal, R. P., Paroha, S., Sahu, R. and Ranganatha. A. R. G. (2013). Study on genetic divergence in sesame (sesamum indicum 1.) Germplasm based on morphological and quality traits. The Bioscan. 8(4): 13871391.

\section{How to cite this article:}

Maumita Burman, S.K. Nair and Sarawgi, A.K. 2019. Genetic Diversity Analysis in Unique Rice (Oryza sativa L.) of Chhattisgarh, India. Int.J.Curr.Microbiol.App.Sci. 8(11): 1096-1099. doi: https://doi.org/10.20546/ijcmas.2019.811.129 